\title{
Kehilangan sebagian gigi pada rongga mulut
}

\author{
Krista V. Siagian \\ Program Studi Pendidikan Dokter Gigi Fakultas Kedokteran \\ Universitas Sam Ratulangi Manado \\ Email: veroagian@yahoo.com
}

\begin{abstract}
Missing teeth or tooth decay will influence many things in human life, not only aesthetically but also mastication, speech, and social interaction. Caries and periodontal diseases are the major causes of this tooth problem. This study aimed to report a clinical case of an adult female aged 39 years who had missing teeth approximately 5 years ago that changed her extra-oral and intra-oral appearance. Due to the missing teeth, migration and rotation of the remained teeth occurred, food remnants were impacted into the interdental gaps which could increase gum diseases, asymetry of face, disposition of buccal and lips' soft tissue, and reduced thickness of alveolar bone ridges. Partial denture can prevent the adverse changes in the oral cavity caused by the missing teeth.
\end{abstract}

Keywords: missing teeth, periodontal diseases

\begin{abstract}
Abstrak: Kehilangan gigi sebagian akan memengaruhi banyak hal dalam diri seseorang, baik estetis maupun fungsi pengunyahan, bicara, dan hubungan sosial. Karies dan penyakit periodontal merupakan penyebab utama masalah gigi ini. Laporan kasus ini bertujuan untuk menampilkan gambaran klinis seorang wanita berusia 39 tahun dengan keluhan kehilangan gigi sebagian kurang lebih 5 tahun lalu yang mengubah tampilan ekstra oral maupun intra oral. Kehilangan sebagian gigi berakibat migrasi dan rotasi dari gigi tersisa, impaksi makanan dan timbulnya penyakit periodontal, asimetris wajah, perubahan letak jaringan lunak pipi dan bibir, serta beban berlebih pada jaringan penyokong yang mengakibatkan turunnya linggir dan menipisnya tulang alveolar. Pemakaian gigi tiruan parsial dapat mencegah terjadinya perubahan-perubahan yang terjadi dalam rongga mulut akibat kehilangan gigi.
\end{abstract}

Kata kunci: kehilangan gigi, penyakit periodontal

Kehilangan gigi merupakan masalah kesehatan gigi dan mulut yang banyak muncul di masyarakat karena sering menggangu fungsi pengunyahan, bicara, estetis, bahkan hubungan sosial. Karies dan penyakit periodontal merupakan penyebab utama penyakit ini. ${ }^{1}$ Berdasarkan laporan RISKESDAS (Riset Kesehatan Nasional) 2013, angka prevalensi nasional penyakit gigi dan mulut sebesar 25,9\%. Kehilangan gigi nasional pada usia 35-44 tahun sebesar sebesar $0,4 \%$ yang semakin meningkat pada usia 65 tahun ke atas $(17,6 \%){ }^{2}$ Persentase kehilangan gigi di Sulawesi Utara lebih tinggi daripada angka nasional yaitu sebesar $0,9 \%{ }^{2} \quad$ Menurut Dinas Kesehatan Kota Manado tahun 2012 sebanyak 1.187 orang memperoleh tindakan pencabutan gigi di Kota Manado, sedangkan data mengenai penggunaan gigi tiruan belum ada. ${ }^{3}$

Menurut Gerritsen, hilangnya satu atau beberapa gigi dapat menyebabkan gangguan fungsi dan estetika yang dapat memengaruhi kualitas hidup seseorang. ${ }^{1,4}$ Hasil penelitian Aisyiah $^{5}$ mengenai hubungan kehilangan gigi dan kualitas hidup terkait kesehatan gigi dan mulut pada pegawai paruh baya di Universitas Bung Hatta, menyatakan bahwa seseorang yang 
kehilangan 5-9 gigi mempunyai kualitas hidup yang buruk sedangkan kehilangan $>10$ gigi mempunyai kualitas hidup yang sangat buruk. ${ }^{5}$

Kehilangan gigi dapat berpengaruh terhadap aktivitas sosial. ${ }^{1,4}$ Hal ini selaras dengan pendapat McGrath bahwa kehilangan gigi dapat memengaruhi keadaan fisik seperti penampilan estetik, terganggunya sistem mastikasi, dan memengaruhi kenyamanan bicara. ${ }^{6}$ Hasil penelitian Wong menemukan bahwa kehilangan gigi geligi dapat memengaruhi keadaan fisik dan psikologis, seperti kurangnya percaya diri dan keterbatasan aktifitas sosial. $^{6}$

Kehilangan gigi juga dapat dihubungkan dengan tingkat sosial ekonomi, tingkat pendidikan, dan penghasilan. Seseorang yang berpendidikan dan mempunyai penghasilan cukup akan serta rutin melakukan perawatan gigi dan mulut., ${ }^{1,4}$ Beberapa faktor yang memengaruhi masyarakat terhadap kebutuhan pemakaian gigi tiruan di antaranya estetis, sosial, fungsional, pendidikan, dan faktor kebudayaan. ${ }^{1,4,7}$ Banyaknya jumlah kehilangan gigi tentunya akan membuat tuntutan atau keinginan akan pembuatan gigi tiruan meningkat guna mengembalikan fungsi gigi geligi yang hilang.

\section{LAPORAN KASUS}

Seorang wanita yang berusia 39 tahun berdomisili di Tumiting, Manado datang ke RSGM PSPDG FK Unsrat dengan keluhan merasa tidak nyaman karena kehilangan gigi sudah kurang lebih 5 tahun yang lalu, juga merasa malu karena kehilangan gigi depan atas, dan kesulitan saat mengunyah makanan. Pasien meminta untuk dibuatkan gigi palsu.

Gambar profil ekstraoral pasien dari depan terlihat bentuk muka lonjong dan asimetri terhadap garis tengah wajah, dan bentuk wajah pasien dari samping cembung (Gambar 1).

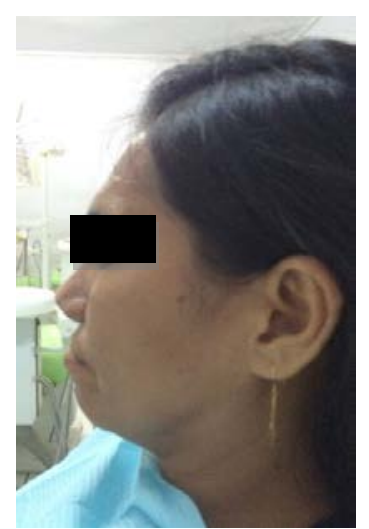

Gambar 1. Profil ekstraoral pasien yang kehilangan gigi. A, Tampak depan; B, Tampak samping
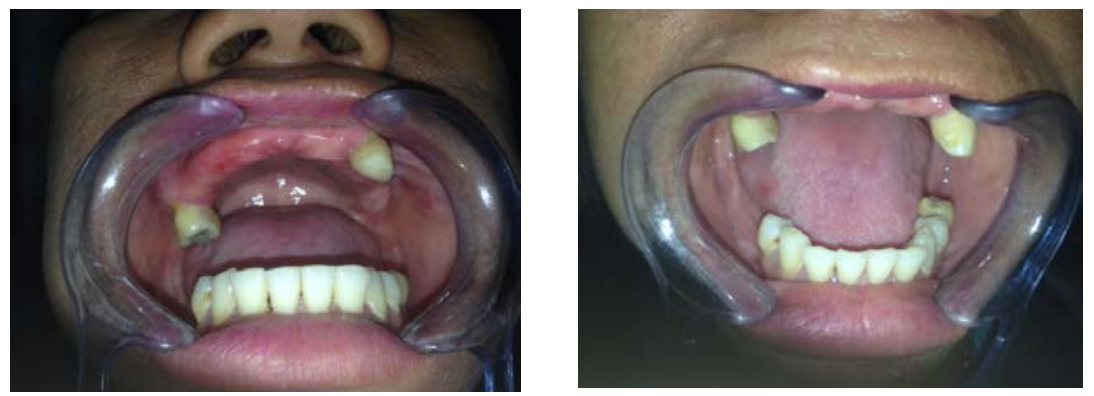

Gambar 2. Profil intraoral pasien yang kehilangan gigi. A, Rahang atas; B, Rahang bawah 
Gambar 2 memperlihatkan kehilangan gigi yang multipel pada rahang atas dan bawah. Kondisi gingiva normal (berwarna merah muda, tak mudah berdarah, tidak bengkak, serta perlekatan dengan tulang alveolar baik).

\section{BAHASAN}

\section{Dampak kehilangan gigi tanpa adanya penggantian}

Gambar 1 dan 2 menunjukkan berbagai akibat yang muncul karena kehilangan gigi, yaitu migrasi dan rotasi gigi. Hilangnya kesinambungan pada lengkung gigi dapat menyebabkan pergeseran, miring atau berputarnya gigi. Karena gigi ini tidak lagi menempati posisi yang normal untuk menerima beban yang terjadi pada saat pengunyahan maka akan mengakibatkan kerusakan struktur periodontal. Gigi yang miring sulit dibersihkan, sehingga aktivitas karies meningkat. ${ }^{1}$

Erupsi berlebih yang terlihat pada gigi penyangga molar dan caninus (Gambar 2).

Bila gigi sudah tidak mempunyai antagonis lagi, maka akan terjadi erupsi berlebih (overeruption). Erupsi berlebih dapat terjadi tanpa atau disertai pertumbuhan tulang alveolar. Bila hal ini terjadi tanpa pertumbuhan tulang alveolar, maka struktur periodontal akan mengalami kemunduran sehingga gigi mulai ekstrusi. Bila terjadinya hal ini disertai pertumbuhan tulang alveolar berlebih, maka akan menimbulkan kesulitan jika pada suatu hari penderita perlu dibuatkan geligi tiruan lengkap. ${ }^{1}$

Gambar 1 menunjukkan profil luar pasien yang asimetri akibat gangguan fungsi otot pengunyahan. Penurunan efisiensi kunyah merupakan dampak yang akan ditimbulkan akibat kehilangan gigi terutama pada bagian posterior. Pada kelompok orang yang dietnya cukup lunak, hal ini mungkin tidak terlalu berpengaruh. ${ }^{1}$ Gambar 1 juga menunjukkan usaha otot wajah untuk penutupan berlebih (over closure). Hal ini diakibatkan kehilangan gigi sehingga terjadi kebiasaan menguyah yang buruk, penutupan berlebih (over closure), serta hubungan rahang yang eksentrik, dapat menyebabkan gangguan pada struktur sendi rahang. ${ }^{1}$

Gambar 2 menunjukkan beban berlebih pada jaringan pendukung, turunnya linggir dan tulang alveolar. Bila penderita sudah kehilangan sebagian gigi aslinya, maka gigi yang masih ada akan menerima tekanan mastikasi lebih besar sehingga terjadi pembebanan berlebih (over loading). Hal ini akan mengakibatkan kerusakan membran periodontal dan lama kelamaan gigi tersebut menjadi goyang dan akhirnya dicabut. ${ }^{1}$

Gambar 2 menunjukkan kehilangan gigi depan atas dan bawah yang sering menyebabkan gangguan fungsi bicara, karena gigi khususnya yang depan termasuk bagian organ fonetik. ${ }^{1}$ Gambar 1 dan 2 menunjukkan memburuknya penampilan seseorang akibat kehilangan gigi. Menjadi buruknya penampilan (loss of appearance) karena kehilangan gigi depan akan mengurangi daya tarik wajah seseorang, apalagi dari segi pandang manusia modern. ${ }^{1}$

Kehilangan gigi menyebabkan terganggunya kebersihan mulut. Migrasi dan rotasi gigi menyebabkan gigi kehilangan kontak dengan gigi tetangganya, demikian pula pada gigi antagonisnya. Adanya ruang interproksimal ini mengakibatkan terbentuknya celah antar gigi yang mudah disisipi sisa makanan. Dengan sendirinya kebersihan mulut jadi terganggu dan mudah terbentuk plak; bila tidak diperhatikan maka akan menyebabkan angka kejadian karies meningkat. ${ }^{1}$

Pada kasus tertentu dimana membran periodontal gigi masih menerima beban berlebih tetapi belum mengalami kerusakan dan masih dalam keadaan sehat. Toleransi terhadap beban ini biasa berwujud atrisi pada geligi, sehingga dalam jangka waktu yang lama akan terjadi pengurangan dimensi vertikal wajah pada saat gigi dalam keadaan oklusi sentrik. ${ }^{1}$

Kehilangan gigi menyebabkan kerusakan terhadap jaringan lunak mulut, seperti bibir, pipi, lidah. Bila ada gigi yang hilang, ruang yang ditinggalkannya akan ditempati jaringan lunak pipi dan lidah. 
Jika berlangsung lama, hal ini akan menyebabkan kesukaran adaptasi terhadap gigi geligi tiruan yang kemudian dibuat, karena terdesaknya kembali jaringan lunak tadi dari tempat yang ditempati protesis. Dalam seperti ini, pemakaian gigi geligi tiruan akan dirasakan sebagai suatu benda asing yang cukup mengganggu. ${ }^{1}$

\section{Penyebab kehilangan gigi Karies}

Karies gigi merupakan suatu penyakit jaringan keras gigi, yaitu: email, dentin, dan sementum yang disebabkan oleh aktivitas jasad renik dalam karbohidrat yang dapat diragikan. Streptococcus mutans dan laktobasilus merupakan bakteri kariogenik yang mampu segera membuat asam dari karbohidrat yang dapat diragikan. Tandanya ialah adanya demineralisasi jaringan keras gigi, yang berakibat terjadi invasi bakteri dan kematian pulpa serta penyebaran infeksinya ke jaringan periapeks yang dapat menyebabkan nyeri. ${ }^{8}$

Pada tahap awal karies, rasa nyeri diawali dengan nyeri ringan pada saat kontak dengan makanan atau minuman yang dingin atau panas, juga rasa nyeri yang sesekali muncul secara tajam. Bila bakteri sudah sampai ke pulpa gigi yang terdiri dari saraf dan pembuluh darah, maka terjadi infeksi pada pulpa (pulpitis) yang menyebabkan nyeri yang sangat berdenyut. Bila hal ini terjadi secara terusmenerusmaka akan terjadi kematian jaringan pulpa. Bila saraf gigi sudah mati biasanya nyeri akan berhenti, namun keadaan ini dapat berlanjut lebih buruk dengan terjadinya abses sehingga pada akhirnya gigi tersebut tidak dapat dipertahankan dan harus dicabut. ${ }^{8}$

\section{Penyakit periodontal}

Penyakit periodontal adalah penyakit yang mengenai jaringan pendukung gigi, yaitu gingiva/gusi serta jaringan periodontal, yaitu jaringan yang menghubungkan antara gigi dan tulang penyangga gigi yaitu tulang alveolar. Penyakit periodontal dibagi atas dua golongan yaitu gingivitis dan periodontitis. ${ }^{9}$

Gingivitis merupakan bentuk penyakit periodontal dengan proses inflamasi yang memengaruhi jaringan lunak sekeliling gigi tanpa adanya kerusakan tulang. Tanda pertama dari inflamasi yaitu adanya hiperemia, warna gingiva berubah dari merah muda menjadi merah tua, disebabkan dilatasi kapiler, sehingga jaringan menjadi lunak karena banyak mengandung darah. Gingiva membengkak, licin, berkilat dan keras, perdarahan gingiva spontan atau bila dilakukan probing, gingiva menjadi sensitif, gatal-gatal dan terbentuknya saku periodontal akibat rusaknya jaringan kolagen. Kelainan tersebut muncul perlahan-lahan dalam jangka lama dan tidak terasa nyeri kecuali bila ada komplikasi dengan keadaan akut. Bila peradangan ini dibiarkan dapat berlanjut menjadi periodontitis. ${ }^{9}$

Periodontitis merupakan lanjutan dari gingivitis yang tidak ditangani. Periodontitis adalah penyakit inflamasi yang akan memengaruhi periodonsium yaitu jaringan yang mengelilingi serta mendukung gigi. Periodontitis akan melibatkan hilangnya progresif dari tulang alveolar pada sekitar gigi, dan bila tidak diobati maka dapat menyebabkan melonggarnya perlekatan jaringan ikat dan hilangnya gigi. ${ }^{9}$

\section{Trauma}

Trauma dapat diartikan sebagai kerusakan jaringan gigi atau periodontal karena kontak yang keras dengan suatu benda yang tidak terduga sebelumnya pada gigi, baik rahang atas maupun rahang bawah atau keduanya. Trauma gigi dapat terjadi secara langsung dan tidak langsung. Trauma gigi secara langsung terjadi ketika benda keras langsung mengenai gigi, sedangkan trauma gigi secara tidak langsung terjadi ketika ada benturan yang mengenai dagu menyebabkan gigi rahang bawah membentur gigi rahang atas dengan kekuatan atau tekanan besar dan tiba-tiba. ${ }^{10}$ Contohnya yaitu pada kecelakaan, jatuh, terbentur benda keras dan berkelahi (dapat menyebabkan gigi patah dan terlepas dari soketnya). ${ }^{9,10}$ 


\section{Alasan pasien pemakai gigi tiruan lepasan: persepsi, penampilan, dansosial ekonomi}

Persepsi adalah suatu stimulus yang diterima oleh sistem saraf. Proses selanjutnya ialah menginterpretasikan stimulus tersebut. Menurut Thoha, persepsi pada hakekatnya adalah proses kognitif yang dialami oleh setiap orang dalam memahami informasi tentang lingkungan baik melalui penglihatan maupun pendengaran. ${ }^{10}$

Penampilan menjadi buruk karena adanya kehilangan akan mengurangi daya tarik seseorang. Penelitian yang dilakukan oleh Davis et al. di London menunjukkan bahwa 45\% dari pasien yang mengalami kehilangan gigi sulit menerima keadaannya. Pasien-pasien ini merasa kurang percaya diri dan tidak ingin dilihat orang lain saat tidak memakai gigi tiruan. Pasienpasien tersebut membutuhkan waktu yang lebih lama untuk menerima kehilangan gigi dan perubahan bentuk wajah. Reaksi emosional yang sering ditemukan pada pasien yang kehilangan gigi ialah rasa sedih dan kehilangan, tidak percaya diri, serta perubahan tingkah laku. ${ }^{10}$

Mengenai sosial ekonomi, Esan et al. menyatakan bila tingkat pendidikan dan penghasilan rendah maka kemungkinan terjadinya kehilangan gigi akan lebih tinggi dibandingkan dengan tingkat pendidikan dan penghasilan tinggi. Hal ini disebabkan karena seseorang dengan tingkat pendidikan yang lebih tinggi akan mengerti bagaimana cara memelihara kesehatan termasuk kesehatan rongga mulut. ${ }^{10}$

\section{Fungsi gigi tiruan lepasan}

Untuk menghindari dampak yang tidak diinginkan akibat hilangnya gigi tanpa ada pengganti maka dibuat suatu alat tiruan sebagai pengganti gigi yang sudah hilang. Secara lebih rinci, fungsi pengganti gigi tiruan dapat diuraikan sebagai berikut:

1. Pemulihan fungsi estetik: Alasan utama seorang pasien mencari perawatan prostodontik biasanya karena masalah estetik, baik yang disebabkan hilangnya gigi geligi, berubah bentuk, susunan, warna maupun berjejalnya gigi-geligi. Hilangnya gigi dapat disebabkan karena karies, penyakit periodontal, trauma atau gigi yang mengalami malposisi dan karena pencabutan. Untuk pasien dengan gigi depan malposisi, protrusif atau berjejal dan tak dapat diperbaiki dengan perawatan ortodontik tetapi tetap ingin memperbaiki penampilan wajahnya, biasanya dibuatkan suatu gigi geligi tiruan imidiat yang dipasang langsung segera setelah pencabutan gigi. ${ }^{1}$

2. Peningkatan fungsi bicara: Alat bicara yang tidak lengkap dan kurang sempurna dapat memengaruhi suara penderita, misalnya pasien yang kehilangan gigi depan atas dan bawah. Kesulitan bicara dapat timbul meskipun hanya bersifat sementara. Dalam hal ini gigi geligi tiruan dapat meningkatkan dan memulihkan kemampuan bicara, artinya ia mampu kembali mengucapkan kata-kata dan berbicara dengan jelas, terutama bagi lawan bicaranya. ${ }^{1}$

3. Perbaikan dan peningkatan fungsi pengunyahan: Pola kunyah penderita yang sudah kehilangan sebagian gigi biasanya mengalami perubahan. Kehilangan beberapa gigi terjadi pada kedua rahang, tetapi pada sisi sama, maka penguyahan akan dilakukan semaksimal mungkin oleh geligi asli pada sisi lainnya. Dalam hal seperti ini, tekanan kunyah akan dipikul satu sisi atau sebagian saja. Setelah pasien memakai protesa, ternyata ia merasa perbaikan. Perbaikan ini terjadi karena sekarang tekanan kunyah dapat disalurkan secara lebih merata keseluruh bagian jaringan pendukung. Dengan demikian protesa ini berhasil mempertahankan atau meningkatkan efisiensi kunyah. ${ }^{1}$

4. Mempertahankan jaringan mulut yang masih tersisa dengan menggunakan gigi tiruan dan mengurangi efek yang timbul karena hilangnya gigi. Pasien yang menggunakan gigi tiruan dapat terbantu mencerna makanan dengan baik, menjaga geligi yang masih ada agar tidak hilang, dan mencegah resorpsi 
tulang alveolar. ${ }^{1}$

5. Pencegahan migrasi gigi: Bila sebuah gigi dicabut atau hilang, gigi tetangganya dapat bergerak memasuki ruang kosong tadi. Migrasi seperti ini pada tahap selanjutnya menyebabkan renggangnya gigi-gigi lain. Dengan demikian terbukalah kesempatan masuknya makan pada celah itu, sehingga mudah terjadi akumulasi plak interdental. Hal ini menjurus pada peradangan periodontal. Bila pasien menggunakan gigi tiruan, hal-hal seperti migrasi dan overerupsi gigi antagonis, akan dapat diatasi dan tidak terjadi kesulitan di kemudian hari. ${ }^{1}$

\section{SIMPULAN}

Pada kasus kehilangan sebagian gigi, terjadi perubahan tampilan ekstra oral maupun intra oral. Kehilangan sebagian gigi berakibat terjadinya migrasi dan rotasi dari gigi tersisa, impaksi makanan dan timbulnya penyakit periodontal, asimetris wajah, perubahan letak jaringan lunak pipi dan bibir, serta beban berlebih pada jaringan penyokong yang mengakibatkan turunnya linggir dan menipisnya tulang alveolar.

Untuk menghindari dampak yang tidak diinginkan akibat hilangnya gigi maka diperlukan pemakaian gigi tiruan parsial atau lengkap tergantung kebutuhan.

\section{DAFTAR PUSTAKA}

1. Gunadi HA, Margo A, Burhan LK, Suryatenggara F, Setiabudi I. Buku Ajar Ilmu Geligi Tiruan Sebagian Lepasan jilid 1. Jakarta:
Hipokrates, 1993; p. 11-47.

2. Departemen Kesehatan Republik Indonesia. Laporan Riset Kesehatan Dasar Nasional 2007. Jakarta: Badan Penelitian dan Pengembangan Kesehatan; 2008. [cited 2015 Jun 15]. Available from: URL: http://www.litbang.depkes.go.id

3. Dinas Kesehatan Kota Manado. Profil kesehatan Kota Manado. Manado: 2012. [cited 2015 Jun15]. Available from URL: http://www.depkes.go.id

4. Natamiharja L. Kebutuhan dan pemakaian geligi tiruan pada lansia di kota madya Medan. Dentika. 1999;38:5965.

5. Aisyah. Hubungan kehilangan gigi dengan kualitas hidup terkait kesehatan gigi dan mulut pada pegawai paruh baya di Universitas Bung Hatta [Skripsi] (tidak dipublikasi). Padang: Universitas Andalas; 2014.

6. Emini. Gigi tiruan dan perilaku ibadah, Jurnal Health Quality. 2013:4(1): 2831.

7. Esan TA, Olusile AO, Akeredolu PA, Esan AO. Socio-demographic factors and edentulism the Nigerian experience. BMC Oral Health. 2004; 4(3):1-6.

8. Kidd EAM, Bechal SJ. Dasar-dasar Karies Penyakit dan Penanggulangannya. Jakarta: EGC, 2013; p. 3.

9. Carranza FA, Newman MG, Takei HH.. Clinical Periodontology (9th ed). Philadelphia: W. B. Saunders Co, 2002.

10. Fiske J, Davis DM, Frances C, Gelbier S. The emotional effects of tooth loss in edentulous people. Br Dent J. 1998;184: 90-3. 